\title{
Seroprevalence and associated risk factors of human Brucella infection in selected provinces in Sri Lanka
}

\author{
L Karunanayake ${ }^{1}$, P Karunanayake ${ }^{2}$, C S Rathnayaka ${ }^{1}$, U Senarath ${ }^{3}$, J M Ranbanda ${ }^{1}$, M Kothalawala $^{4}$ \\ (Index words: Brucellosis, human Brucella infection, Prevalence, Risk factors, Sri Lanka)
}

\begin{abstract}
Brucellosis is a systemic zoonotic bacterial infection. We studied the seroprevalence and risk factors for human Brucella infection in 1,294 healthy people from 4 provinces: Central, North-Western, North-Central and Western Provinces. Farmers in contact with farmanimals, veterinary staff, abattoir workers, and noncontact urban-dwellers were tested against $B$. abortus and $B$. melitensis antigens by SAT. Seroprevalence was $8.4 \%$ of the study population. Farm-animal owners and working full-time with livestock have a significantly higher risk of acquiring Brucella infection. Enhanced laboratory support and surveillance is necessary to control brucellosis in Sri Lanka. This is the first report on human Brucella infection.
\end{abstract}

Ceylon Medical Journal 2019; 64: 25-29

DOI: http://doi.org/10.4038/cmj.v64i1.8824

\section{Introduction}

Brucellosis is a systemic bacterial zoonosis. It is transmitted by ingestion through food products, direct contact with infected animals and inhalation of aerosols. Transmission through blood transfusion or tissue transplantation and sexual transmission are rare possibilities. Although the disease has been well known for decades, it continues to be a major public health issue worldwide [1].

The true incidence of human brucellosis is unknown globally, as many countries known to be endemic for brucellosis, such as India and South Africa, do not have reliable data on the disease [2].

Brucella are small aerobic intracellular coccobacilli, that live mainly in the reproductive organs of wild and domestic animals. There are 8 species identified, but $B$. melitensis, B. suis, B. abortus and B. canis cause disease in humans. Although B. melitensis is thought to be the most virulent species, $B$. abortus is the most commonly distributed species worldwide [1]. Livestock farmers, slaughterhouse workers and veterinarians are at high risk of developing the disease. Travelers and urban residents usually acquire the infection through the consumption of contaminated food especially raw milk or milk products [3]. The disease was introduced to Sri Lanka during the second world war, through the importation of cattle. The first clinical outbreak in livestock was reported in 1956 [4,5]. The North-Western and North-Central Provinces with the highest density of cattle, were implicated as endemic areas for brucellosis[4]. However, a meta-analysis in 2013 has shown that data is not available for human brucellosis in Sri Lanka[6].

We studied the seroprevalence of human Brucella infection and associated risk factors among high-risk occupations such as farmers, veterinarians and abattoir workers in Central (CP), North-Western (NWP), NorthCentral (NCP) and Western (WP) Provinces.

\section{Methods}

The study was conducted in 2014/2015 among 9 districts in the 4 Provinces. The 41 veterinary divisions and their farms were randomly selected by probabilityproportional-to-size sampling technique. Veterinary staff, abattoir workers and non-contact urban-dwellers were recruited by convenient sampling.

A total of 1,294 blood samples were collected from farmers in contact with farm animals (818), veterinary staff (190), abattoir workers (137) risk categories and noncontact urban-dwellers (149). The study used a nonrandom purposive sampling method. Standard tube Agglutination Test (SAT) was performed using B. abortus and $B$. melitensis antigens (MAST ${ }^{\mathrm{TM}}$ Assure febrile stained antigen, UK) according to manufacturer's guidelines at clinical bacteriology laboratory, Medical

\footnotetext{
${ }^{1}$ Department of Bacteriology, Medical Research Institute, Colombo, ${ }^{2}$ Department of Clinical Medicine, Faculty of Medicine, University of Colombo, ${ }^{3}$ Department of Community Medicine, Faculty of Medicine, University of Colombo, ${ }^{4}$ Base Hospital Polonnaruwa, Sri Lanka.
}

Correspondence: LK, e-mail: <lilani_k@hotmail.com>. Received 19 December 2018 and revised version accepted 06 March 2019. 
Research Institute. A titer of 1:80 was considered for seropositivity (past infection). Socio-demographic data were collected using an interviewer-administered questionnaire.

\section{Statistical analysis}

Data entry and statistical analyses were performed using SPSS version 21. Quantitative data were obtained in the form of percentages and figures. Cross tabulations were generated between seroprevalence and sociodemographic factors, and the Pearson $\chi^{2}$ test was used to express the statistical significance of any associations. $\mathrm{P}$-values of 0.05 or less were considered to be significant. The potential risk factors for seropositivity were also assessed using bivariate analyses and presented as Odds Ratio(OR).

\section{Results}

A total of 1,294 healthy adults were screened. Sample size was sufficient to estimate sero-prevalence of brucellosis at $50 \%$ in the study population. The level of precision is $95 \%$ with confidence interval $3 \%$ and the nonresponse rates was $15 \%$. Males constituted $81.9 \%$ and the mean age was 45.6 years (Table 1 ). SAT was negative in $1,185(91.6 \%)$ of the study population and positive in 104 (8.4\%). The overall seroprevalence for human Brucella infection was $8.4 \%$. SAT showed seropositivity of $7.5 \%$ for B. abortus and $3.2 \%$ for B. melitensis. The risk occupations had a significant seropositivity compared to non-contact residents $(\mathrm{p}=0.04)$. Farm animal owners showed a significant seropositivity, in comparison to noncontact residents $(\mathrm{OR}=3.0, \mathrm{p}<0.05)$ [Table 2,3]. Analysis of specific high-risk behaviors such as assisting in animal delivery, duration and degree of animal contact, and consumption of raw milk did not show significant associations with seropositivity. Individuals with full-time exposure to animals $(\mathrm{p}=0.01)$ had a significantly higher risk of developing the Brucella infection than part-time workers. Being a livestock farmer with animal contact $(p=0.03)$ yielded a significantly higher risk than for veterinary staff or abattoir workers [Table 2,3].

Table 1. Distribution and composition of the study sample

\begin{tabular}{lcc}
\hline Description & $\begin{array}{c}\text { Number }(n) \\
\text { participated }\end{array}$ & $\%$ \\
\hline Province & & \\
W P & 403 & 31.1 \\
CP & 166 & 12.8 \\
NWP & 356 & 27.5 \\
NCP & 369 & 28.5 \\
Risk categories & & \\
Animal-husbandry owners & 596 & 46 \\
Part-time animal handlers & 216 & 16.6 \\
Veterinary staff & 192 & 14 \\
Abattoir workers & 141 & 10.8 \\
Urban-dwellers & 149 & 11.5 \\
\hline
\end{tabular}

Table 2. Distribution of seropositivity to Brucella infection according to socio-demographic and occupational characteristics ( $n=1294)$

\begin{tabular}{|c|c|c|c|c|c|c|}
\hline & Characteristic & $\begin{array}{l}\text { Seropositivity } \\
(n)\end{array}$ & $\%$ & Total & Chi-square & $P$ value \\
\hline \multirow[t]{2}{*}{ Gender } & Male & 83 & $7.8 \%$ & 1060 & 2.7 & 0.102 \\
\hline & Female & 26 & $11.1 \%$ & 234 & & \\
\hline Age category & $<30$ & 15 & $11.8 \%$ & 127 & 11.6 & 0.020 \\
\hline \multirow[t]{4}{*}{ (in years) } & $31-40$ & 21 & $7.1 \%$ & 297 & & \\
\hline & $41-50$ & 44 & $10.0 \%$ & 438 & & \\
\hline & $51-60$ & 14 & $4.6 \%$ & 304 & & \\
\hline & $>60$ & 15 & $11.7 \%$ & 128 & & \\
\hline \multirow[t]{5}{*}{ Risk Occupations } & Animal husbandry owner & 65 & $10.9 \%$ & 596 & 10.9 & 0.027 \\
\hline & $\begin{array}{l}\text { Handling farm animals } \\
\text { (part-time) }\end{array}$ & 12 & $5.6 \%$ & 216 & & \\
\hline & Veterinary staff & 15 & $7.8 \%$ & 192 & & \\
\hline & Abattoir workers & 11 & $7.8 \%$ & 141 & & \\
\hline & Non-contact persons & 6 & $4.0 \%$ & 149 & & \\
\hline
\end{tabular}


Brief report

\begin{tabular}{|c|c|c|c|c|c|c|}
\hline & Characteristic & $\begin{array}{c}\text { Seropositivity } \\
(n)\end{array}$ & $\%$ & Total & Chi-square & $P$ value \\
\hline \multirow{5}{*}{$\begin{array}{l}\text { Duration of } \\
\text { risk occupation }\end{array}$} & $0-10$ years & 44 & $9.6 \%$ & 460 & \multirow[t]{5}{*}{1.6} & \multirow[t]{5}{*}{0.813} \\
\hline & 11-20 years & 37 & $7.7 \%$ & 483 & & \\
\hline & 21-30 years & 19 & $8.0 \%$ & 238 & & \\
\hline & $31-40$ years & 8 & $8.7 \%$ & 92 & & \\
\hline & $41-50$ years & 1 & $4.8 \%$ & 21 & & \\
\hline Risk Occupation vs. & Risk occupations & 103 & $9.0 \%$ & 1145 & 4.2 & 0.040 \\
\hline Urban-dwellers & Non-contact group & 6 & $4.0 \%$ & 149 & & \\
\hline Working in & Yes & 12 & $7.8 \%$ & 154 & .090 & 0.764 \\
\hline slaughter house & No & 97 & $8.5 \%$ & 1140 & & \\
\hline \multirow[t]{5}{*}{ Type of livestock } & Cattle only & 50 & $8.3 \%$ & 602 & \multirow[t]{5}{*}{4.5} & \multirow[t]{5}{*}{0.337} \\
\hline & Water buffaloes only & 5 & $14.7 \%$ & 34 & & \\
\hline & Goat only & 2 & $10.5 \%$ & 19 & & \\
\hline & Swine only & 1 & $16.7 \%$ & 6 & & \\
\hline & Mix herd & 24 & $12.6 \%$ & 190 & & \\
\hline \multirow[t]{3}{*}{ Working with livestock } & Full time & 51 & $10.8 \%$ & 474 & \multirow[t]{3}{*}{6.9} & \multirow[t]{3}{*}{.032} \\
\hline & Part time & 34 & $8.3 \%$ & 410 & & \\
\hline & No & 24 & $5.9 \%$ & 410 & & \\
\hline \multirow[t]{4}{*}{ Degree of contact } & Habitual contact & 85 & $8.7 \%$ & 982 & \multirow[t]{4}{*}{3.5} & \multirow[t]{4}{*}{0.320} \\
\hline & Frequent contact & 10 & $10.3 \%$ & 97 & & \\
\hline & Less frequent contact & 5 & $11.9 \%$ & 42 & & \\
\hline & No contact & 9 & $5.2 \%$ & 173 & & \\
\hline \multirow{7}{*}{$\begin{array}{l}\text { Duration of Contact } \\
\text { with animals }\end{array}$} & No contact & 9 & $5.5 \%$ & 163 & \multirow[t]{7}{*}{3.8} & \multirow[t]{7}{*}{0.705} \\
\hline & $>20$ years & 34 & $8.9 \%$ & 382 & & \\
\hline & $15-19$ years & 14 & $8.6 \%$ & 162 & & \\
\hline & 10-14 years & 11 & $6.6 \%$ & 167 & & \\
\hline & $5-9$ years & 22 & $9.3 \%$ & 236 & & \\
\hline & 1-4 years & 16 & $10.3 \%$ & 155 & & \\
\hline & $<1$ year & 3 & $10.7 \%$ & 28 & & \\
\hline \multirow[t]{2}{*}{ Drinking raw milk } & Yes & 4 & $7.5 \%$ & 53 & \multirow[t]{2}{*}{0.06} & \multirow[t]{2}{*}{0.815} \\
\hline & No & 105 & $8.5 \%$ & 1241 & & \\
\hline Study Prevalence & & & $8.40 \%$ & 1294 & & \\
\hline
\end{tabular}


Table 3. Univariate regression analysis for being seropositive to Brucella infection: Odds ratio for socio-demographic and occupational risk factors $(n=1294)$

\begin{tabular}{|c|c|c|c|c|}
\hline \multicolumn{5}{|c|}{$95 \%$ C.I. for $O R$} \\
\hline Variable & Unadjusted $O R$ & Lower & Upper & $P$ value \\
\hline \multicolumn{5}{|l|}{ Gender } \\
\hline$\underline{\text { Female }}$ & 1.000 & & & \\
\hline Male & .680 & .427 & 1.082 & .104 \\
\hline \multicolumn{5}{|l|}{ Age } \\
\hline$\leq 30 \mathrm{yrs}$ & 1.000 & & & \\
\hline $31-40$ & .568 & .283 & 1.142 & .112 \\
\hline $41-50$ & .834 & .447 & 1.554 & .567 \\
\hline $51-60$ & .360 & .169 & .771 & .009 \\
\hline$>60$ & .991 & .463 & 2.123 & .982 \\
\hline \multicolumn{5}{|l|}{ Occupation } \\
\hline$\underline{\text { Non-contact persons }}$ & 1.000 & & & .033 \\
\hline Animal husbandry own & 2.917 & 1.239 & 6.870 & .014 \\
\hline Handling farm animals part-time & 1.402 & .514 & 3.822 & .509 \\
\hline Veterinary staff & 2.020 & .764 & 5.339 & .156 \\
\hline Abattoir workers & 2.017 & .725 & 5.608 & .179 \\
\hline \multicolumn{5}{|l|}{ Duration of risk Occupation } \\
\hline$\underline{0-10 \text { years }}$ & 1.000 & & & .816 \\
\hline $11-20$ years & .784 & .497 & 1.239 & .298 \\
\hline 21-30 years & .820 & .467 & 1.439 & .490 \\
\hline $1-40$ years & .900 & .409 & 1.982 & .794 \\
\hline 41-50 years & .473 & .062 & 3.608 & .470 \\
\hline \multicolumn{5}{|l|}{ Occupation risk } \\
\hline$\underline{\text { Non-risk occupations }}$ & 1.000 & & & \\
\hline Risk occupations & 2.356 & 1.016 & 5.465 & .046 \\
\hline \multicolumn{5}{|l|}{ Risk of animal exposure } \\
\hline$\underline{\text { Non-contact }}$ & 1.000 & & & \\
\hline Animal contact & 2.497 & 1.067 & 5.841 & .035 \\
\hline Vet staff & 2.020 & .764 & 5.339 & .156 \\
\hline Abattoir & 2.017 & .725 & 5.608 & .179 \\
\hline \multicolumn{5}{|l|}{ Working in slaughter house } \\
\hline$\underline{\text { No }}$ & 1.000 & & & \\
\hline Yes & 1.101 & .589 & 2.056 & .764 \\
\hline \multicolumn{5}{|l|}{ Type of livestock } \\
\hline$\underline{\text { Mix herd }}$ & 1.000 & & & \\
\hline Cattle only & .627 & .374 & 1.050 & .076 \\
\hline Water buffaloes & 1.193 & .421 & 3.378 & .740 \\
\hline Goat only & .814 & .177 & 3.744 & .791 \\
\hline Swine only & 1.383 & .155 & 12.351 & .771 \\
\hline \multicolumn{5}{|l|}{ Working with livestock } \\
\hline$\underline{\text { No }}$ & 1.000 & & & \\
\hline Full-time & 1.939 & 1.171 & 3.211 & .010 \\
\hline Part-time & 1.454 & .846 & 2.499 & .175 \\
\hline \multicolumn{5}{|l|}{ Degree of contact } \\
\hline$\underline{\text { No contact }}$ & 1.000 & & & \\
\hline Habitual contact & 1.727 & .852 & 3.501 & .130 \\
\hline Frequent contact & 2.095 & .820 & 5.348 & .122 \\
\hline Less frequent & 2.462 & .780 & 7.776 & .125 \\
\hline \multicolumn{5}{|l|}{ Duration of contact } \\
\hline$\underline{\text { No contact }}$ & 1.000 & & & \\
\hline$>20$ years & 1.672 & .783 & 3.570 & .184 \\
\hline 15-19 years & 1.619 & .680 & 3.853 & .276 \\
\hline $10-14$ years & 1.207 & .486 & 2.993 & .685 \\
\hline $5-9$ years & 1.759 & .788 & 3.926 & .168 \\
\hline $1-4$ years & 1.970 & .843 & 4.600 & .117 \\
\hline$<1$ year & 2.053 & .520 & 8.107 & .305 \\
\hline \multicolumn{5}{|l|}{ Drinking raw milk } \\
\hline$\underline{\text { No }}$ & 1.000 & & & \\
\hline Yes & .883 & .313 & 2.495 & .815 \\
\hline
\end{tabular}

"Reference category is underlined 


\section{Discussion}

Brucellosis has been recognized as a re-emerging zoonosis due to growing international tourism, migration and potential use as a biological weapon. In Sri Lanka, animal brucellosis is an endemic disease, causing economic impact to the livestock industry [4].

One clinically suspected case of human brucellosis has been briefly described in a Sri Lankan patient from Monaragala four-decades ago [7]. Since then, no reports were available on human disease in Sri Lanka. Our study shows a seroprevalence of $8.4 \%$ for human Brucella infection and the most common species detected serologically was $B$. abortus.

In animal brucellosis, B. abortus has been reported as the common species in Sri Lanka [4]. In the 1980s, cases of caprine brucellosis due to $B$. melitensis were reported and more recently, in swine in Sri Lanka $[6,8]$. High incidence of animal brucellosis was reported from Eastern, NCP and NWP [5].

Close contact with animals and raw milk ingestion has been attributed as the major risk factors in Karnataka in India [9]. In our study, farm animal owners and full-time handlers of livestock showed significant seropositivity than part-time livestock handlers and non-contact groups and only 53 persons ingested raw milk [Table 2,3]. This signifies the variations in risk factors for brucellosis in different countries.

In conclusion, the seroprevalence for human Brucella infection is $8.4 \%$. Farm-animal owners and those working full-time with animal husbandry have a significantly high risk of acquiring the infection. This is the first report on human Brucella infection in Sri Lanka.

Awareness of the disease among clinicians, and enhanced laboratory diagnostic support and surveillance in human and animal brucellosis are recommended to control brucellosis in Sri Lanka.

\section{Acknowledgements}

The Director General and the Director of Animal Production and Health, Provincial Directors, Veterinary Surgeons and staff of the Medical Research Institute are greatly appreciated.

\section{Conflicts of interests}

The authors declare that they have no conflicts of interests.

\section{Funding}

This work was supported by the Medical Research Institute, Ministry of Health, Sri Lanka.

\section{Declarations}

Ethics approval and consent to participate:

Ethics approval was obtained from the Ethics Review Committee, Medical Research Institute, Sri Lanka (32/2011). Background data on farms were obtained from the District Veterinary Surgeons through the Director General of Animal Health and Production. Written consent was obtained from participants.

\section{References}

1. Beeching NJ. Brucellosis. In: Kasper DL, Fauci AS, Hauser SL, Longo DL, Jameson JL eds. Harrison's Principles of Internal Medicine, $20^{\text {th }}$ edition V1. New York; McGrawHill Education, 2018: 1192-1200.

2. Mantur BG, Amarnath SK. Brucellosis in India - Review. In: J. Biosci. 2008; 33: 539-47.

3. Young EJ. Brucella species. In: Bennett JE, Dolin R (editors). Mandell, Douglas and Bennett's Principles and Practice of Infectious Diseases, $7^{\text {th }}$ edition. Philadelphia: Elsevier, Churchill Livingstone, 2010; 2921-25.

4. Priyantha MAR. Identification of biovars of Brucella abortus in aborted cattle and buffaloe herd in Sri Lanka. Veterinary World 2011; 4: 542-45.

5. Priyantha MAR, Puvanendran S, Wijemuni MI, Gunawardana GA, Appuhamy GS, and Fernando PS. Spatial distribution of Brucella abortus seropositive cases in cattle during 2001-2007; A case study of using GIS in improving the recommended control strategies in Sri Lanka. In: $5^{\text {th }}$ National Symposium on Geo-Informatics for sustainable Development, Colombo. 2008; 135-48.

6. Gunawardena N, Chandrasekera S, Hettiarachchi G, Perera S, Jagoda S, Fernando P, et al. Brucellosis in Sri Lanka: A review of the epidemiology and control strategies, and recommendations for future control strategies. In: South Asia Regional (SAR) One Health Symposium. 2013; 52-3.

7. Goonaratne C. Brucellosis in Humans and Animals. Ceylon Medical Journal 2009; 52(2): 66.

8. Fernando P, Weerasooriya KMSG, Liyanagunawardena N, Bandara WMPB, Munasinghe MND, Wijemuni MI. Isolation and identification of $B$. melitensis from a swine herd in Sri Lanka. In: Program and Abstracts of the $69^{\text {th }}$ Annual Scientific Sessions of the Sri Lanka Veterinary Association. May, 2017: p10.

9. Smita SM, Annapurna GS, Sivajirao TM, Satish V, Kakade et al. Serological, clinical and epidemiological profile of human brucellosis in rural India. Indian J Community Med 2015; 40: 163-67. 